\title{
Schools of the Basilian Sisters in Jaworów during the Galician autonomy 1867-1918
}

\begin{abstract}
In the latter half of the nineteenth century, Galicia became an autonomous province within the Dual Monarchy. In addition to political reforms, changes in education were also proposed. Polish language and the teaching of Polish history were introduced to schools. Furthermore, private schools for girls were founded, with an objectives to raise their level of education and prepare them for studies at universities. Schools run by religious congregations played a significant role. These were mainly Catholic orders. Schools were also run by the Basilian Sisters of the Ukrainian Greek Catholic rite (Ordo Sancti Basilii Magni). They had their convent in Jaworów in Galicia, where they founded an elementary school, a teachers seminar and a boarding house for girls. The language of instruction was Ukrainian. Monastic schools operated on the same principles as state schools, they taught the same subjects, and used the same textbooks. School authorities carried out inspections of monastic schools every year. The schools enjoyed a good reputation and had a high level of teaching.
\end{abstract}

Keywords: Private Schools, Galician Authonomy, Education, Church in Poland

For a long time, issues related to the functioning of monastery schools for girls in the Galician autonomy were modestly presented in Polish historiography. They appeared as part of studies on the history of education in Galicia or the history of individual Catholic congregations. The articles published in "Nasza Przeszłość" are important for the discussed problem. These include publications by Bogusława Czajecka', Ewa Jabłońska-

${ }^{1}$ B. CZAJECKA, Szkoty klasztorne żeńskie w Galicji w latach 1867-1914, Nasza Przeszłość (further on as NP), vol. 61:1984. The situation with regard to the education of girls in Catholic schools in the period before the partitions was slightly better. Particular attention should be paid to the work of A. SZYLAR, Działalność wychowawczo-edukacyjna żeńskich zgromadzeń zakonnych w Małopolsce w okresie potrydenckim do 1815 roku, Kraków 2012. 
-Deptułowa ${ }^{2}$, Betrix. Banaś ${ }^{3}$. They concern the educational activity of various religious congregations in Poland. Monographs on the education provided in selected religious congregations have been published since the 1990s. A monograph on the School of the Presentation Sisters in Cracow by Renata Gąsior and sister Teresa Matuła was an important contribution to learning about education for girls ${ }^{4}$. A monograph on the schools of the Ursuline Sisters in Tarnów by Anna Rogozińska has also been published ${ }^{5}$. A monograph by sister Elżbieta Albiniak on the Sisters of Divine Providence, devoted mainly to the care and educational activity of the congregation, is also worth mentioning ${ }^{6}$. A significant position among the studies concerning private education is the monograph by Aleksandra Bilewicz on private secondary schools for girls functioning in Galicia in the analysed pe$\operatorname{riod}^{7}$. This monograph also includes schools run by religious congregations.

This brief and selective literature on the subject concerns mainly activities in the field of education in female Catholic religious congregations. Very little attention was paid to Uniate education. This is probably due to the lack of Polish studies on the education offered by the Basilian Sisters. Access to Ukrainian studies is hampered due to language difficulties. The article by Salomi Cioroch, which presents a fairly detailed description of the schools of Basilian Sisters, run not only in Galicia, but also abroad, is particularly noteworthy ${ }^{8}$. While preparing this article, I used the archival material contained in the

${ }^{2}$ E. JABŁOŃSKA-DEPTUŁA, Zakony diecezji przemyskiej od pierwszego rozbioru do 1938 r., NP, vol. 46: 1976.

3 B. BANAŚ, Urszulanki polskie $w$ dobie „Kulturkampfu”, NP, vol. 7:1985.

${ }^{4}$ R. GĄSIOR, T. MATUŁA, Szkoła Sióstr Prezentek w Krakowie w latach 1627-1918, Lublin 1998.

${ }^{5}$ A. ROGOZIŃSKA, Szkoly Sióstr Urszulanek w Tarnowie w latach 1877-1953, Lublin 2002.

${ }^{6}$ E.M. ALBINIAK, Działalność opiekuńczo-wychowawcza Zgromadzenia Sióstr Opatrzności Bożej w latach 1857-1905, Lublin 2004; also see: O. DUCH, Losy monasterów bazylianek w Galicji na przełomie XVIII i XIX wieku [in:] Kasaty klasztorów na obszarze dawnej Rzeczypospolitej Obojga Narodów i na Ślasku na tle procesów sekularyzacyjnych w Europie, ed. M. Derwich. Wrocław, 2014, Vol. 1, pp. 233-247. The literature on the subject of male education in the period before 1773 is much richer. Basilian education in the seventeenth and eighteenth centuries was the topic of the work of: L. BIEŃKOWSKI, Organizacja Kościoła wschodniego w Polsce, [in:] Kościót w Polsce, vol. II: Wieki XVI-XVIII, ed. J. KŁOCZOWSKI, Kraków 1969, pp. 1015-1025; M. PIDŁYPCZAK MAJEROWICZ, Bazylianie w Koronie i na Litwie. Szkoły i książki w działalności zakonu, Warsaw-Wrocław 1986, pp. 28-55; M.M. WOJNAR, Basilian seminaries, college and schools (XVII-XVIII), Analecta Ordinis S. Basilii Magni, sectio II, vol. IX, 1974, fasc. 1-4, pp. 48-63; І. ПАТРИЛО, Нарис історії Василіян від 1743 до 1839 року, [in:] Нарис історії Василіянського Чину святого Йосафата, Рим 1992, pp. 239-244; D. WEREDA, Bazylianie w unickiej diecezji brzeskiej $w$ XVIII wieku, Szkice Podlaskie 8/2000, pp. 213-233; R. DOBROWOLSKI, Szkoly bazyliańskie w Żyrowicach XVIII-XIX w., [in:] Małe miasta. Religie, ed. M. ZEMŁO, Lublin-Supraśl 2006, pp. 411-467; B. LORENS, Szkoły przy klasztorach bazyliańskich $w$ Galicji na tle austriackiej polityki oświatowej w latach 1772-1850, [in:] Historia i dziedzictwo regionów w Europie Środkowo-Wschodniej w XIX i XX w., ed. M. STOLARCZYK, A. KAWALEC, J. KUZICKI, Rzeszów 2011; also: Bazylianie w Galicji wobec działań kasacyjnych w latach 1772-1792, [in:] Kasaty klasztorów na obszarze dawnej Rzeczypospolitej..., pp. 215-231; also, Problemy wychowawcze w szkołach bazyliańskich $w$ drugiej połowie XVIII wieku na przykładzie kolegium $w$ Buczaczu, https://repozytorium.amu.edu.pl/bitstream/10593/13399/1/B.Lorens.pdf [14.12.2017].

${ }^{7}$ A. BILEWICZ, Prywatne średnie ogólnokształcace szkolnictwo żeńskie w Galicji w latach 1867-1914, Wrocław 1997.

${ }^{8}$ S. CIOROCH, Pogliad na istoriu i wychownu dijalnist monachiń wasijenok, Rome 1964. 
Central Archives of Historical Records in Warsaw in the collections of the Ministry of Denominations and Education and in the collections of the Central Historical Archive of Ukraine in Lviv (dispersed files). Normative files, statistical materials, printed reports of the National School Council and reports presented to the National School Council by school inspectors in charge of visiting the schools proved to be helpful. Due to the modest source materials and scarce studies, the text presented below serves only as a starting point for a possible further study of Uniate Education in the Galician autonomy. This is a very interesting and explorable issue. Unlike Catholic congregations, the congregation of Basilian Sisters created and successfully ran all types of schools that were functioning in Galicia, though in a fewer number than Catholic schools. In Lviv the Basilian Sisters established the only private lower secondary school for girls in Galicia, which opened the way to higher education for girls.

The Basilian Sisters, Sisters of the Order of Saint Basil the Great, are a habitual order of the Byzantine-Ukrainian rite. It was founded in Asia Minor in the 4th century by St. Macrina, the sister of St. Basil the Great. This took place around the year 354 in Annesis near Caesarea on the Iris River. Its rule is the basis of the religious life of the sisters. The Rule of the Order was approved in 363 by Pope Liberius. The Order developed rapidly, establishing numerous monasteries in Egypt, Sicily and southern Italy. Finally, the Turkish invasions reduced the number of monasteries. The Basilian Sisters settled in Kievan Rus during the reign of Jarosław Mądry, who built the first female order of St. Irena. Under pressure from the Orthodox Church, some orders passed to his side. Basilian monasteries were reborn in the 16th century, mainly as a result of the Brest Union of 1596. Basilian religious houses were built in Poland: in Vilnius, Bytyń and Pińsk. The flourishing of religious life took place at the end of the 19th century. The Basilian Sisters were active throughout the entire area of Ukraine. They took care of young people and children, established schools and boarding houses, where they taught various professions. A monastery in Przemyśl was built in 1902. With regard to spiritual life, the sisters set the goal of achieving holiness, i.e. perfect love. The foundation of Basilian spirituality is the combination of contemplative life and active life for the benefit of the people. The main purpose of the Order is to praise God through choir prayers and individual prayers, lead an evangelical way of life and apply the three vows: of chastity, poverty, and obedience ${ }^{9}$. The Basilian Sisters have been operating in Poland until today and have four monastic houses. They serve mainly the faithful of the Greek Catholic rite.

Educational and pedagogical activities of the Basilian Sisters in Ukraine developed rapidly in the 19th century, but the beginnings date back to an earlier time. However, there are hardly any sources left to investigate the activity of the nuns. This is justified by the fact that little attention has been paid to the education of girls. If they were sent to a monastery, this was to serve as preparation for monastic service and the girls were taught only reading and writing. More information has been preserved about the educational activities of Basilian fathers. It was not until the 18th century that information appeared that the Basilian Sisters had been recommended by the synod to educate girls and accept tuition

\footnotetext{
${ }^{9}$ B. ŁOZIŃSKI, Leksykon zakonów w Polsce, Warsaw 2002, pp. 147-148.
} 
fees. This may suggest that the aim was not only to prepare future nuns, but also to practice wider education. It also improved the economic situation of the Order. The establishment and activity of the National Education Commission (KEN) after the First Partition of Poland meant that it also supervised the establishments run by religious congregations and imposed its curriculum of education and training. However, this did not cover all the lands of the Republic of Poland, as Galicia, which after the First Partition of Poland fell under Austrian rule, was excluded. In 1770, Empress Maria Theresa ordered the organisation and development of schools in the Austrian monarchy. According to the project, schools were divided into three levels: trivial urban and rural, real and lower secondary schools. Religious congregations were not perceived as educational institutions, and their existence was not in the interest of the state. However, the collapse of the said projects meant that monasteries retained the right to teach and educate. It was profitable for the state, as monasteries did not receive any subsidies for education from the state treasury, while relieving the education system subsidized by the monarchy. The economic interest prevailed and the Basilian Sisters, among others, were allowed to maintain schools. This situation also turned out to be beneficial for the church, as monasteries which dealt with the upbringing and education of children justified their existence in the monarchy. However, the Lviv metropolitan, Michał Lewicki, was required to report on the number of religious educators, their education, the number of educated girls and the educational curriculum implemented in accordance with the guidelines of the state and the interests of the Habsburg monarchy. The result was an imperial permit for the schools of Basilian Sisters to operate in Lviv and Słowita, provided they would not receive any support from governmental authorities.

Changes taking place in the Austro-Hungarian Empire in the second half of the 19th century had an impact on the internal politics of individual provinces, including the Polish territories of the Austrian partition, i.e. Galicia. The liberalisation of politics, changes in the political system, the polonization of offices and institutions and the revival of social life had an impact on education. The concessions in education policy were important for the education of girls in Galicia. Previously, schools for girls were few in number and at elementary level, supplemented by boarding schools for girls. As a result of political changes, social expectations regarding women's education and the popularisation of their access to secondary school examinations and tertiary education also evolved. The situation changed in 1869 with the enactment of the law on the establishment and operation of private schools.

The new conditions determining the functioning of the education system led to the revival of private schools for girls, including those run by religious congregations, aimed at the upbringing and education of girls at various levels. The educational activity of the Orders was also caused by economic reasons. Fees paid by the students and state subsidies gave the nuns a chance for a dignified life. Monastery schools in Galicia operated on the same principles as those established for state schools. The schools were administered by the educational authorities of Galicia, i.e. the National School Council with its seat in Lviv, which granted them a permit to establish the school and the Ministry of Denominations and Education granted them the rights of state schools. It was possible to 
obtain such rights provided that school regulations prepared by the educational authorities were followed and the curriculum of state schools was implemented. Religious institutions were obliged to use school textbooks approved by the school authorities, and were annually visited by school inspectors, obliged to provide scrupulous reports on their visits. On this basis, the so-called "public rights" (i.e. the same rights as those granted to public schools) were granted to religious schools and, by fulfilling the requirements, such schools could issue school certificates equivalent to those of state schools, as well as apply for state subsidies.

\section{Elementary school}

The educational and pedagogical activity of the monastery in Jaworów dates back to 1847 , when the monastery of the Basilian Sisters was reopened. In the same year, a school for girls was established which, under Austrian law, consisted of three classes. Two classes at elementary level and the third at trivial level. Elementary classes educated students on a lower or higher level. The language of instruction was German and students were taught the following: the alphabet, pronunciation, grammar, reading in Polish, German and Ukrainian, calligraphy, counting, grammar of the three languages and their translation, as well as dictations. The curriculum of the trivial class was basically the same, but homework was also assigned. Such a division lasted until 1854, when grade III and a year later grade IV were introduced. The elementary divisions, on the other hand, were eliminated. The four-grade school lasted until 1880, when grade V and a year later grade VI were introduced. The school served as a preparatory school for a teacher's seminar for girls established in 1906. It was not until World War I that the school was extended by grade VII. In 1870, the school began to teach supplementary subjects, such as French, singing, drawing and piano lessons. Initially, the language of instruction was German, but later also Ukrainian, except for geography, which was taught in German. The attendance at the school, taking into account the small number of units, was significant. In 1849 $25,1852-37,1853-40,1854-60$ students (at that time grade III was launched). In later years the number of students was comparable and ranged between 60 (1878) and 88 (1888) students. 1897 turned out to be a special year, when as many as 100 students attended the school. The number of students started to decrease in the time of the Second Polish Republic due to the modest conditions of the school's premises, a small number of classrooms and facilities and, consequently, the inability to open individual units.

In the initial period of the school's activity, instruction was provided only by the nuns under the supervision of a clergyman who taught religion. The school was subordinate to the assistant bishop, as evidenced by the teachers' patents granted to sister Anastazja Kulmatycka and Onisima Czerniak by the assistant bishop in 1851. Later, lay people were also recruited as teachers and entrusted with school management. Most often, 7-11 teachers were employed, of whom 3-5 were lay people. The pedagogical supervision of the school was entrusted to both religious and lay people. After establishing the teacher's seminar and transforming the school into a preparatory school for the seminar, the principal of the seminar also became the school administrator. The school was not intended exclusively for students of the Greek Catholic faith. Both Roman Catholic and Jewish girls 
learned there ${ }^{10}$.The opening of Ukrainian elementary schools was of crucial importance, as Poles had an advantage in the number of schools functioning in the area. Ukrainians usually had one or two-grade schools mainly in rural areas, which was a disadvantage compared to Polish schools. The didactic organisation of Ukrainian education was much worse. Textbooks written by German authors were first translated into Polish and then into Ukrainian. This affected their sense and the culture of the language. Therefore, the Ukrainian society undertook efforts to strengthen elementary education with the help of educational associations seeking to establish schools that would develop national awareness ${ }^{11}$.

\section{Teachers seminar}

The effective operation of the faculty school run by the Basilian Sisters in Jaworów, which was a small provincial town, its popularity and the growing number of students justified the initiative to establish a secondary school.

The policy of the Galician educational authorities was clearly lacking in enthusiasm for educating teachers. Schools were established on the initiative and under pressure of educational circles and the developing emancipation movement. The first project of a seminar for girls was prepared in 1869. As a result, in 1871, 3 state seminars for girls were established. The attendance grew from year to year, which justified the need for their existence. The inflow of female candidates was so high that only $50 \%$ of the girls who passed the entrance exams were admitted. The reluctance of educational authorities to this form of education manifested itself, among other things, in lowering scholarships, reducing classes and even in extending the period of education by one year. The inefficiency of the public school system and the ever-increasing demand for the development of girls' education were reflected in the establishment of private seminars. It was a spontaneous phenomenon, supported by social circles. Private teachers seminars began to be established in the 1890s. Until the First World War, 35 such seminars were founded in Galicia, 8 of which were seminars led by religious congregations, including 2 by the Basilian Sisters (in Jaworów and Stanisławów). Not all seminars offered education at a high level, those that had the rights of public schools were most significant.

The teachers seminar conducted by the Basilian Sisters in Jaworów was opened in the school year 1906/1907 on the basis of a permit issued by the Ministry of Denominations and Education on 13 September 1906 and on 10 December the National School Council approved the organisation's statutes. The seminar was granted public rights in 1914 .

The school's statutes explicitly stated that it was to educate teachers in general and vocational knowledge and develop the skills of the candidates ${ }^{12}$. The institution also had the

${ }^{10}$ S. CIOROCH, Pogliad na istoriu..., pp.104-106.

11 A. KARAMANOV, Stan ukraińskiego szkolnictwa ludowego [in:] Szkolnictwo i oświata w Galicji 1772-1918, Rzeszów 2015, pp. 348-349.

12 Organisation - the statutes and curriculum of the private teacher education institution of the Basilian Sisters - convent in Jaworów. Central Archives of Historical Records in Warsaw (further on as AGAD), Records of the Ministry of Denominations and Education (MWiO), $275 \mathrm{u}, \mathrm{p} .100$. 
ambition of undertaking educational activities and shaping the character of future teachers of common schools. The subjects included: religion, pedagogy with practical exercises, Polish and Ukrainian as languages of instruction, German, geography, history, arithmetic and geometry, biology, natural history, calligraphy, art, music and singing, viola lessons, manual works and gymnastics. History lessons focused on general history, the Habsburg monarchy and the history of the home country. Biology lessons also included hygiene and dentistry. The classes were conducted by a school physician, who was also responsible for the students' health and for controlling the hygiene of the school premises. The school's statutes also allowed for the teaching of other languages which were allowed in the schools of Galicia as approved by the Ministry of Denominations and Education.

The languages of instruction were Polish and Ukrainian. In grades II, III and IV, arithmetic, geometry and natural history were taught in Ukrainian and history and physics in Polish. Schooling included 4 courses. The neighbouring 4-grade common school allowed for practical exercises. The number of students in each course was limited to 40 . The Basilian Sisters also run a boarding house next to the school, where the students lived and ate. Not all students lived in the boarding school, some attended the school while living in the town or with relatives. The tuition fee for the 1 st and 2 nd course was 12 kroner per month and for the 3rd and 4th course - 14 kroner. The duration of the school year, the semesters and holidays were the same as in the case of other secondary schools in Galicia. The school was subject to state supervision and control, represented by officials appointed by the National School Council. Although the school was opened for Greek Catholic girls, it was also accessible to Roman Catholic and Jewish girls. This was nothing unusual in the multinational and multidenominational Habsburg monarchy. Monastic schools run by Roman Catholic religious congregations also accepted Jewish students and Greek Catholics. This is confirmed by data from e.g. schools run by the Ursuline Sisters.

In order to function as a public school, the school was obliged to submit the timetable and the school's statutes to the educational authorities for approval. Any change to these documents required ministerial approval. The function of school principal and teachers could only be performed by persons with full qualifications for teaching in secondary schools and documented experience in pedagogical work. Although exceptions to this provision were allowed, only the Minister could decide on the approval of a teacher without full qualifications.

The school authorities paid close attention to the housing conditions of the schools. Private schools had to fulfil particularly high demands in this area. The seminar of the Basilian Sisters was rated positively in this respect. The school was housed in a large garden on the outskirts of the town, in its own building, and was adapted to school needs. Each classroom had its own room and classes in gymnastics and violin were held in separate, specially adapted rooms. Didactic classes being part of the internship were conducted by the students in a four-grade folk school with Ukrainian as the language of instruction $^{13}$.

\footnotetext{
${ }^{13}$ Report of the National Inspector of Schools from the inspection of the private teachers seminar for girls in Jaworów, AGAD, records of MWiO, 275 u, p. 170.
} 
The Basilian Sisters provided pre-school education, prior to admission to the seminar, in a specially created class. Those educated in the town school were also admitted. Candidates who studied at home were not denied admission as well. The basic requirement was the mastery of the language of instruction and proficiency in numeracy. To be accepted to the first grade the candidate had to be at least 15 years old, physically well-developed, with an impeccable reputation, and well prepared in terms of merit. Girls with mental disorders, speech defects and striking physical disability were not admitted. The preparation of the candidates was verified by means of a difficult entrance examination or by completing the entry class at the Basilian Sisters' school with a good result. Recruitment for the next school year took place at the end of the given school year. If there were not enough candidates, it was possible to admit candidates in a supplementary recruitment process prior to the beginning of the next school year. The school principal announced the recruitment process, making sure that it would reach the interested parties and their caretakers in a timely manner. The candidates also confirmed admission directly to the school principal in writing or in person. Future students were required to provide: a birth and baptismal certificate, the last school certificate, a certificate of morality and a certificate issued by a doctor who confirmed that the girls were able to learn in this type of school. The survey form was very detailed, it examined the family status, the diseases not only of the candidate, but also of the parents and siblings, and the vaccination status. The doctor defined the girls' nourishment, skin condition (rash, growths, ulceration) - anything that could arouse the disgust of others. Candidates who were crippled were not accepted. This included scoliosis, shorter limbs or their lack, paresis or convulsions of the limbs or face. Eyesight and hearing, pronunciation (lisp or stuttering) were carefully examined. Tuberculosis was very much feared, and the girls had their lungs examined very thoroughly. The doctor also had to testify about the good mental condition of the future teachers ${ }^{14}$.

If the candidates met the formal requirements, they could take the entrance examination. Its preparation and organization was the responsibility of the school principal and teachers appointed by him. The examination covered the following subjects: religion, the language of instruction, German, counting and geometry, and calligraphy. The students' drawing and manual skills were also tested on the basis of the drawings and hand-work submitted by the candidates. The girls' musical skills and knowledge were also checked, as well as whether they showed a sense of rhythm and musical hearing. This was to provide effective music lessons and a balanced level of education. The entrance examination was oral and written and checked the knowledge and skills of the common school curriculum. The admission was decided by a group of teachers headed by the principal of the school. The documentation from the entrance exams included: written works of the entrance exam, minutes from the oral exams, school certificates provided, drawings, handworks. If the candidates obtained equal examination results and it was impossible to admit all of them, priority was given to the candidate who was older. The school statutes also re-

${ }^{14}$ Certificate of health and physical fitness for the teaching profession, Central Archive of Ukraine in Lviv, fond 178. description 3, case 1023. 
served the right to remove students from the school during the course of schooling. If a girl turned out incapable or lazy during the first three months of schooling in the first year, she could be expelled from school. Candidates who showed very good results, good preparation and were of an appropriate age, could be admitted one year higher. However, this had to be confirmed by the results of the difficult examination, which guaranteed knowledge of the issues and skills required at a given level of education.

Weekly timetable in the school year 1913/14

\begin{tabular}{|c|c|c|c|c|c|}
\hline No. & Subject & Grade I & Grade II & Grade III & Grade IV \\
\hline 1. & Religious education & 2 & 2 & 2 & 2 \\
\hline 2. & Pedagogy with practical exercises & - & 2 & 4 & 9 \\
\hline 3. & Polish & 3 & 3 & 3 & 3 \\
\hline 4. & Russian & 3 & 3 & 3 & 3 \\
\hline 5. & German & 3 & 3 & 3 & 3 \\
\hline 6. & Geography & 2 & 2 & 2 & 1 \\
\hline 7. & History & 2 & 2 & 2 & 1 \\
\hline 8. & $\begin{array}{l}\text { Arithmetic and the science } \\
\text { of geometrical forms }\end{array}$ & 3 & 3 & 2 & $\begin{array}{l}\text { I } 1, \\
\text { II } 2\end{array}$ \\
\hline 9. & Natural history & 2 & 2 & 2 & $\begin{array}{l}\text { I } 2 \\
\text { II } 1\end{array}$ \\
\hline 10. & Physics & 2 & 2 & 2 & 1 \\
\hline 11. & Calligraphy & 1 & - & - & - \\
\hline 12. & Hand drawing & 2 & 2 & 2 & 1 \\
\hline 13. & Music and singing lessons & 1 & 1 & 1 & 1 \\
\hline 14. & Feminine crafts & 2 & 1 & 1 & 1 \\
\hline 15. & Violin lessons & 1 & 1 & 1 & 1 \\
\hline 16. & Gymnastics & 2 & 2 & 2 & 2 \\
\hline & Total & 31 & 31 & 32 & 32 \\
\hline
\end{tabular}

Source: Files of the Ministry of Denominations and Education, 1848-1914, AGAD, ref. $458 \mathrm{u}$.

Just like the faculty school, the seminar was subordinate to the school authorities. In its form and organization, scope and requirements, the Basilian Sisters' school was no different than the state schools. It was inspected by the National School Council, which acted with the help of school inspectors visiting the institutions under their supervision every year. These inspections were very detailed. They concerned the implementation of the school curriculum, the introduction of teaching methods and the analysis of school achievements. Attention was paid to the substantive and pedagogical preparation of teachers. The school inspectors inspected all the subjects, checked the students' written work, their topics and number. Attention was paid to the behaviour of students who spent their 
out-of-school time in the boarding house, school garden or classrooms ${ }^{15}$. The results were discussed in detail and recorded during teachers' conferences summing up the inspection. The inspectors presented a list of teacher errors and omissions, as well as guidelines to be applied. Positive follow-up comments were also provided. It was emphasised that the teachers worked with teaching resources that were considered sufficient in number ${ }^{16}$. Attention was paid to the condition of the school building, the number and arrangement of classrooms, teaching aids, order and educational care. A positive result of the inspection increased the chance of obtaining an extension of public schools rights, which was the basis for functioning in the school system. The first school inspection took place in the school year 1911/12 and turned out satisfactory. In 1914, the first secondary school leaving examination took place in the seminar. It was taken by 12 students and turned out successful, as all the students received their secondary school leaving certificate.

The number of students in the seminar gave the school a chance to survive. This is summarised in the table below.

\begin{tabular}{|c|c|c|}
\hline School year & $\begin{array}{c}\text { Number } \\
\text { of courses }\end{array}$ & $\begin{array}{c}\text { Number } \\
\text { of students }\end{array}$ \\
\hline $1906 / 7$ & I & 25 \\
\hline $1907 / 8$ & I-II & 46 \\
\hline $1908 / 9$ & I-II & 43 \\
\hline $1909 / 10$ & I-III & 61 \\
\hline $1910 / 11$ & I-III & 53 \\
\hline $1911 / 12$ & I-III & 45 \\
\hline $1912 / 13$ & I-IV & 59 \\
\hline $1913 / 14$ & I-IV & 60 \\
\hline $1915 / 16$ & I-III & 38 \\
\hline $1916 / 17$ & I-IV & 69 \\
\hline $1917 / 18$ & I-IV & 73 \\
\hline
\end{tabular}

Sources: Files of the Ministry of Denominations and Education, 1848-1918, AGAD, ref. 258 Reports of the National School Council on the State of Public Education in the School Years 1906-1917.

Only in the school year 1914/15 did the school suspend its activity as a result of the war. Already in the year 1915/16 it returned to normal functioning and only the reduced number of students, resulting also from the lack of the fourth course of study, was a reminder of the war. As a result of military actions, some students returned to their homes or left Galicia with their parents. After the fall of the Austro-Hungarian Empire and the

\footnotetext{
15 Report of the Inspector..., p. 172.

${ }^{16}$ Report of the Inspector..., p. 171.
} 
rebirth of the independent Polish state in 1918, the school continued to operate, although schooling was interrupted for some time due to the Spanish flu epidemic. Another break took place in March 1919, as Jaworów once again became the area of warfare. After the political situation stabilized, the school started to operate regularly and the number of students was constantly increasing, even though graduation no longer brought any significant benefits in terms of future employment ${ }^{17}$.

The principal, Tytus Słoniewski, played an important role in the seminar. He graduated from the Faculty of Philosophy of the University of Lviv, and then was a teacher at the Francis Joseph Gymnasium in Lviv. Ultimately, he gained experience in teacher education by taking up positions in Przemyśl, Lviv and Zaleszczyki. He also had experience as a principal of a seminar for girls in Lviv. T. Słoniewski was very involved in teaching work, he was known for providing material help to students in need and for activating his colleagues. His scientific interests focused on philosophy, history and psychology. He also had scientific ambitions, he was interested in teaching methodology, and published in the magazine "Szkoła". He was an activist of the Pedagogical Society in Kołomyja, and also served as a school inspector. After retiring (in 1905), he headed the private seminar for girls of the Basilian Sisters in Jaworów for ten years ${ }^{18}$. The next and last principal of the seminar was Fr. Aleksander Zalitacz, who managed the seminar and the existing elementary school. He was also a catechist for students of the Greek Catholic faith. The faculty included catechists of both Greek Catholic and the Roman Catholic religions, as well as qualified lay teachers, whose number depended on the number of students. Nuns also constituted a small group of teachers.

A large decrease in the number of students in the school year 1932/33 was connected with the closure of course I. Finally, in 1933, the teachers' seminar was closed and replaced by a new 4-grade lower secondary school. Already in the school year 1933/34, 14 students took up education in grade 1. Michał Nawrocki became the school principal and the teachers were recruited mainly from the local private Ukrainian Os. Makowiej lower secondary school.

\section{Boarding house}

The Basilian Sisters also ran a boarding house. It was the place where the religious upbringing of the young girls was most visible. The school and educational institutions earned their living from the small monastery property, subsidies, tuition fees from students and annual appeals. The monastery also benefited from the legate, which in 1855 amounted to 2000 Rhine goldens, with the obligation of teaching the Polish language at the school by qualified teachers, and the admission of Roman Catholic girls to the school. From 1879 , the monastery received subsidies for its activities amounting to 300 Rhine goldens. In view of the high costs of maintaining the institution, the nuns supported the funds

\footnotetext{
17 S. CIOROCH, Pogliad na ..., pp. 107-109.

18 A. MEISSNER, Ukraińscy nauczyciele $w$ Galicji, [in:] Rola mniejszości narodowych $w$ kulturze i oświacie polskiej w latach 1700-1939, ed. A. BILEWICZ and S. WALASEK, Wrocław 1998, p. 85.
} 
with the organization of annual appeals. After the teachers' seminar was established, the tuition fees also contributed to the school budget. Initially, the boarding house and school were located in old monastic buildings, but due to the growing number of students and the strict requirements of the school authorities, they had to be extended. It was also decided to build an Orthodox church. The monastery received financial aid of 600 goldens from Emperor Franz Joseph for the construction of the school church. A brick church was built, and the monastery building was renovated and modernized. Starting from 1888, the school already had six grades and it was necessary to build a new school building. The repair and construction works took a very long time, but were finally completed in $1889^{19}$.

The schools enjoyed a good reputation throughout the entire period of their operation. Their achievements were often praised in the Ukrainian press, and it was believed they exceeded those of the state schools. The great contribution of the nuns to the upbringing of the girls, the maintenance of order in the schools and the culture of teachers were emphasized. These schools played an important role in fulfilling the aspirations of the Ukrainian intelligentsia. While educating women, it was hoped that they would participate in the development of the society's education in a growing number of ways. In view of the growing number of Ukrainian schools, there was a shortage of women who were fully prepared for the teaching profession in Ukraine. Efforts to create religious schools of the Uniate rite were made by: the episcopate, the teachers and political activists. Parents were less confident in the emerging schools, especially in the initial period of autonomy when they were more eager to send their children to Polish schools. The Ukrainian political parties were not reluctant to the rise in the level of education of women, but differed in their perception of the process. Problems were also caused by national legislation, as it was more difficult to establish a Ukrainian school than a Polish one. However, the difficulties in the founding and operation of religious schools for girls run by religious congregations were gradually overcome. The schools educated the Galician female intelligentsia, which played an important role after the fall of the Austro-Hungarian Empire. They also became actively involved in conscious social life.

\section{Bibliography}

\section{Sources}

Archives of Historical Records

Files of the Ministry of Denominations and Education, $275 \mathrm{U}, 458 \mathrm{U}, 258 \mathrm{U}$

Central Historical Archive of Ukraine in Lviv

Files of the National School Council, Fond 178, description 3

19 S. CIOROCH, Pogliad na..., pp. 112-113. 


\section{Printed sources}

Krajowe ustawy szkolne wraz ze statutem RSK, compiled by Bolesław Baranowski, Lviv 1893.

Ustawy i rozporzadzenia obowiazujace $w$ galicyjskich szkołach średnich, compiled by Henryk Kopia, Lviv 1900.

Zbiór ustaw i rozporzadzeń administracyjnych, prepared by J. Piwocki, Lviv 1898-1907.

Sprawozdania c.k. RSK o stanie wychowania publicznego (school years 1902-1912), Lviv 1903$-1913$.

Sprawozdania c.k. RSK o stanie szkót średnich galicyjskich (school years 1906-1912), Lviv 1907$-1913$.

\section{Studies}

ALBINIAK E.M., Działalność opiekuńczo-wychowawcza Zgromadzenia Sióstr Opatrzności Bożej w latach 1857-1905, Lublin 2004.

BANAŚ B., Urszulanki polskie $w$ dobie „,Kulturkampfu”, NP vol.7:1985.

BILEWICZ A., Prywatne średnie ogólnoksztatcace szkolnictwo żeńskie w Galicji w latach 1867-1914, Wrocław 1997.

CIOROCH S., Pogliad na istoriu i wychownu dijalnist monachiń wasijenok, Rome 1964.

CZAJECKA B., Szkoty klasztorne żeńskie w Galicji w latach 1867-1914, NP vol.61:1984.

GĄSIOR R., MATUŁA T., Szkoła Sióstr Prezentek w Krakowie w latach 1627-1918, Lublin 1998.

JABŁOŃSKA-DEPTUŁA E., Zakony diecezji przemyskiej od pierwszego rozbioru do 1938 r, NP vol.46: 1976.

ROGOZIŃSKA A., Szkoły Sióstr Urszulanek w Tarnowie w latach 1877-1953, Lublin 2002.

KARAMANOV A., Stan ukraińskiego szkolnictwa ludowego [in:] Szkolnictwo i oświata w Galicji 1772-1918, Rzeszów 2015, pp.348-349. 
